\title{
5 Stone Hymn - The Buddhist Colophon of 579 Engraved on Mount Tie, Shandong
}

Two characters, reading Shisong 石頌, Stone Hymn, are engraved on a rocky cliff at Mount Tie, in the northern outskirts of the city of Zoucheng 鄒城 in Shandong Province. ${ }^{1}$ These two characters, written in a stately archaistic seal script, form the title above the text of the Stone Hymn. Its field of script on the slanting granite ${ }^{2}$ surface under the open sky is 17 meters long and 4 meters wide (Figure 5.1). The characters are arranged in twelve columns with 52 characters each. There are, however, some exceptions in this grid: columns five and eight have 53, and column two has 54 characters, while column ten has only 43 characters, because the hymn proper begins with a new column. ${ }^{3}$ As the rock has been exposed to the elements for more than fourteen hundred years, many characters are now effaced and hard to make out. Figures 5.2-3 show a rubbing taken in $2008 .{ }^{4}$ It is so large, that it had to be hung beneath the ceiling, when it was exhibited in the Museum für Ostasiatische Kunst in Cologne in 2009 (Figure 5.4). In spite of its enormous size, the text of the Stone Hymn is dwarfed by the sutra engraved to its right (east). This, a passage from the Great Collection Sutra (Dajijing 大集經), has an overall height of more than 51 meters. The Stone Hymn is one of its three colophons.

1 Measurements:shi $85 \times 76 \mathrm{~cm}$, song $72 \times 77 \mathrm{~cm}$.

2 I thank Rainer Altherr for the mineralogical identification which is "biotite-hornblende granodiorite."

3 Even today, the number of characters in the columns is in dispute. A list of each column with the uncertainty: 52 or 53 for column 3 - gives Aikawa (2003, 150). See also Aikawa (2004). Wang Jun 王鈞 writes in Wang Jun and A Tao (1990, 2): largest column (11) 52 characters, shortest column (10) 43 characters. Lai Fei $(2007,112)$ writes: $43-52$ characters per column, but counts 54 characters in column 2 . Our own counting is evident from the line breaks in the transcription of the text below.

4 Museum für Ostasiatische Kunst Köln and Heidelberger Akademie der Wissenschaften $(2009,63)$.

Ә Open Access. (c) 2019 Lothar Ledderose, published by De Gruyter. (c) BY-NC-ND This work is licensed under a Creative Commons Attribution-NonCommercial-NoDerivatives 4.0 International License.

https://doi.org/10.1515/9783110413083-005 


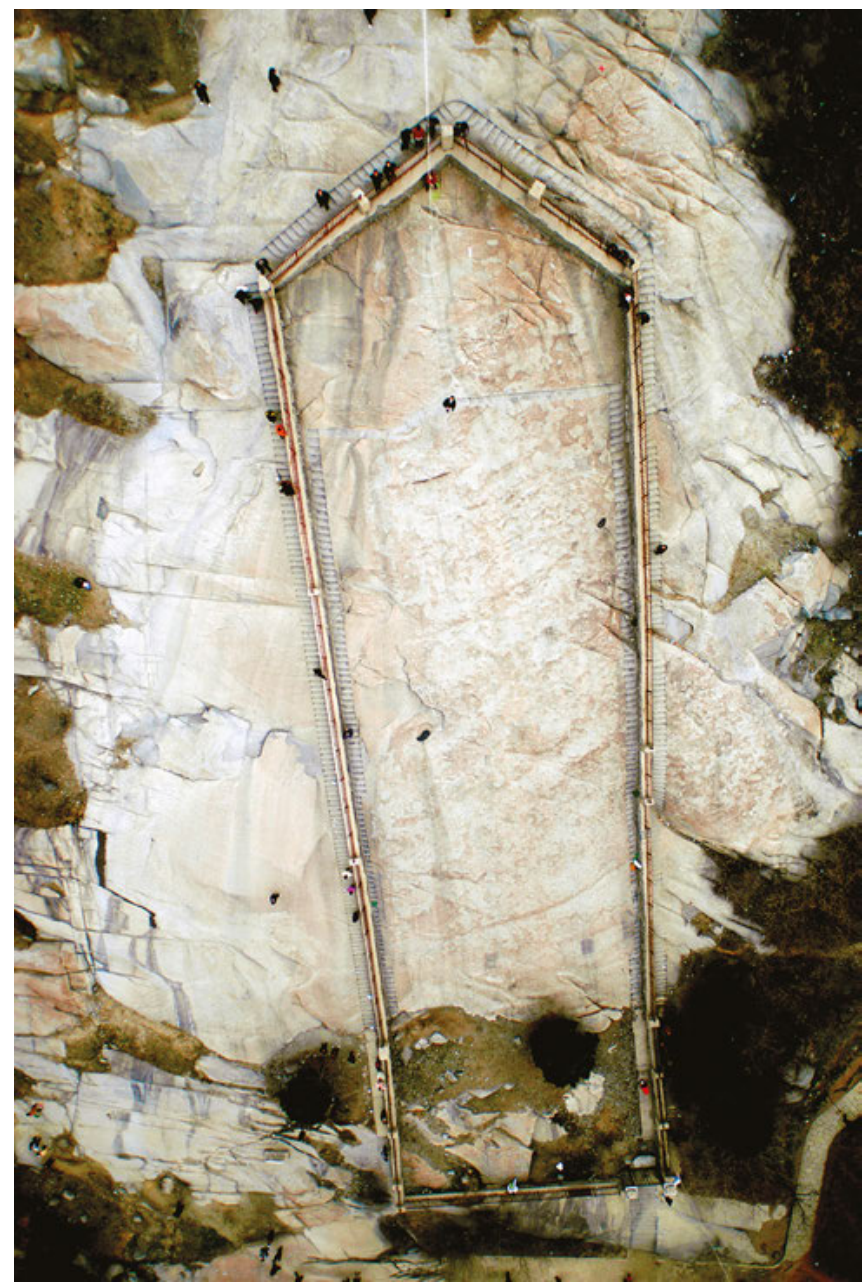

Figure 5.1: Aerial view of the engravings on Mount Tie. The Great Collection Sutra within the fenced field of script on the right, Stone Hymn on the left.

Mount Tie is among the thirty-one sites in Shandong where, during the Northern Qi (Bei Qi 北齊; 551-577), and Northern Zhou (Bei Zhou 北周; 557-581) dynasties Buddhists monks and devout lay persons engraved sutra texts on mountain cliffs, rocks and stelae. These engravings are the subject of 


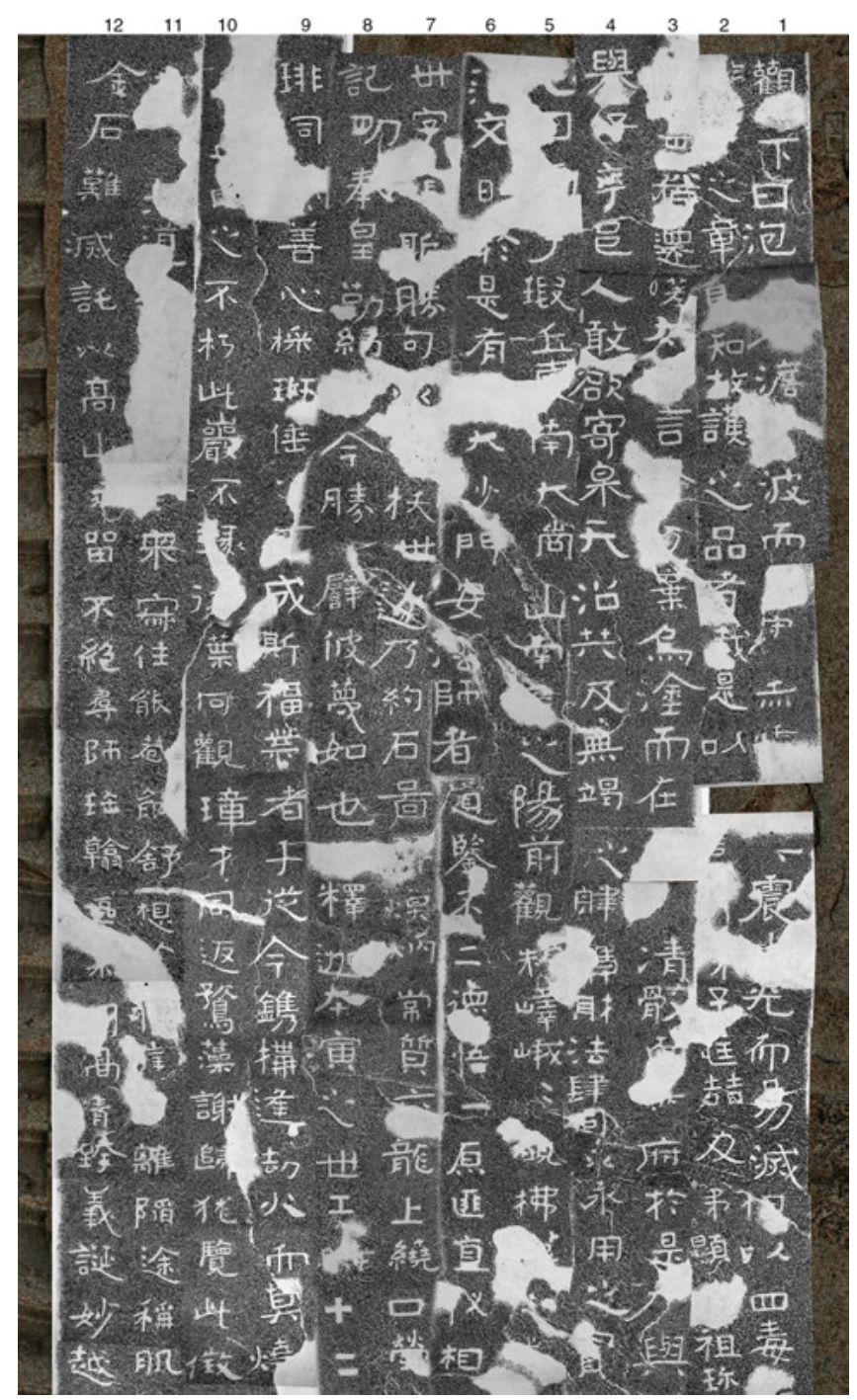

Figures 5.2-3: Stone Hymn. Upper part. Rubbing in four stripes of paper. Made in 2009 by the Shandong Stone Carving Art Museum in Jinan.

a research project that the Heidelberger Akademie der Wissenschaften has been conducting in collaboration with the Shandong Stone Carving Art Museum in Jinan. The results are being published in five volumes in a multivolume series 


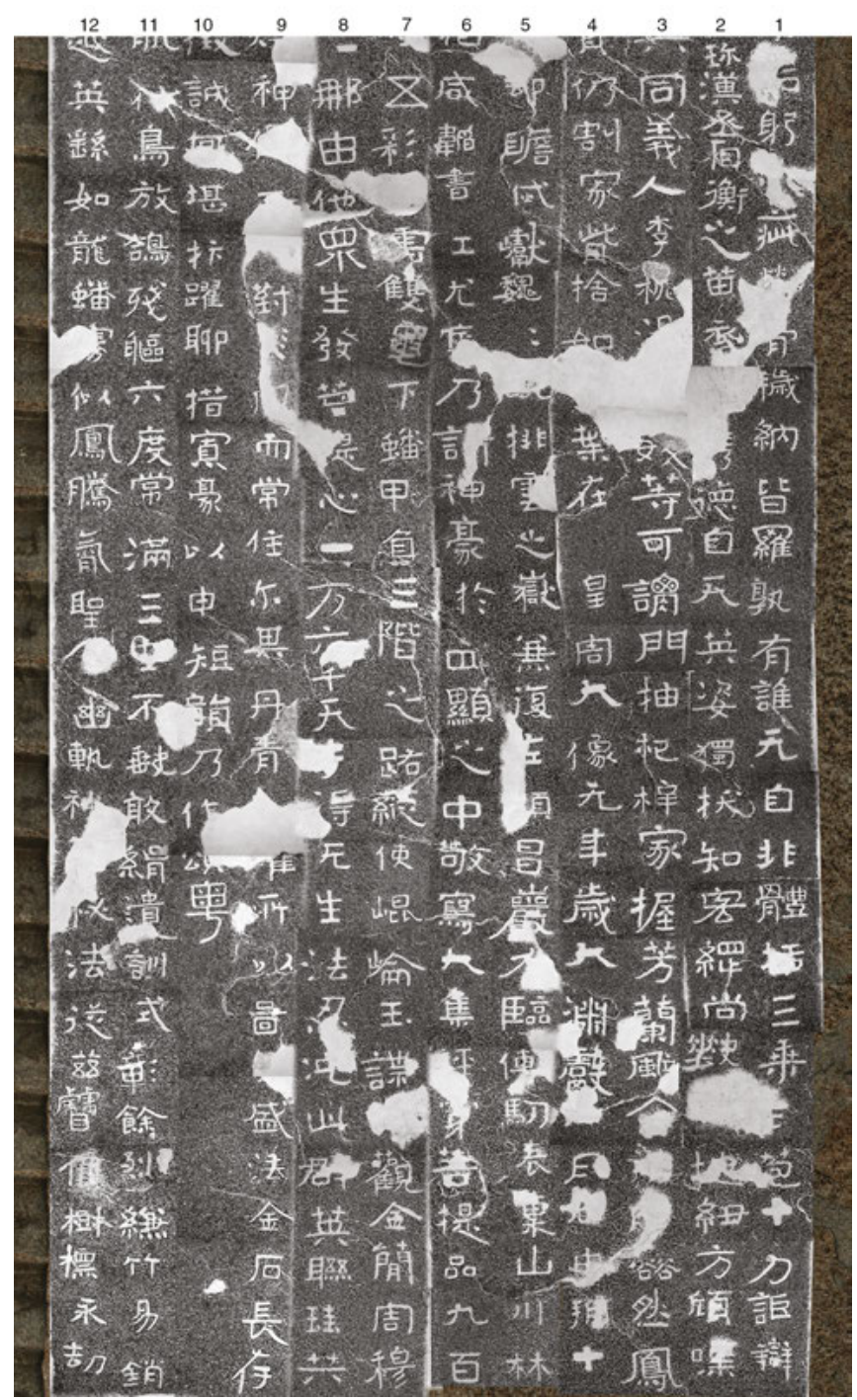

Figures 5.2-3: Lower part (continued)

on Buddhist sutras engraved in stone in China. ${ }^{5}$ The Stone Hymn is one of the many jewels in this material; so far it has gone almost unnoticed. ${ }^{6}$

5 Ledderose (2014 ff., Shandong Province, vols. 1, 2, and 3, and Sichuan Province, vols. 1, 2, 3 and 4, are in print). The Stone Hymn is presented in Shandong Province, vol. 2 (2015), 149-174. 6 For a brief assessment of its various aspects see Ledderose (2016). 


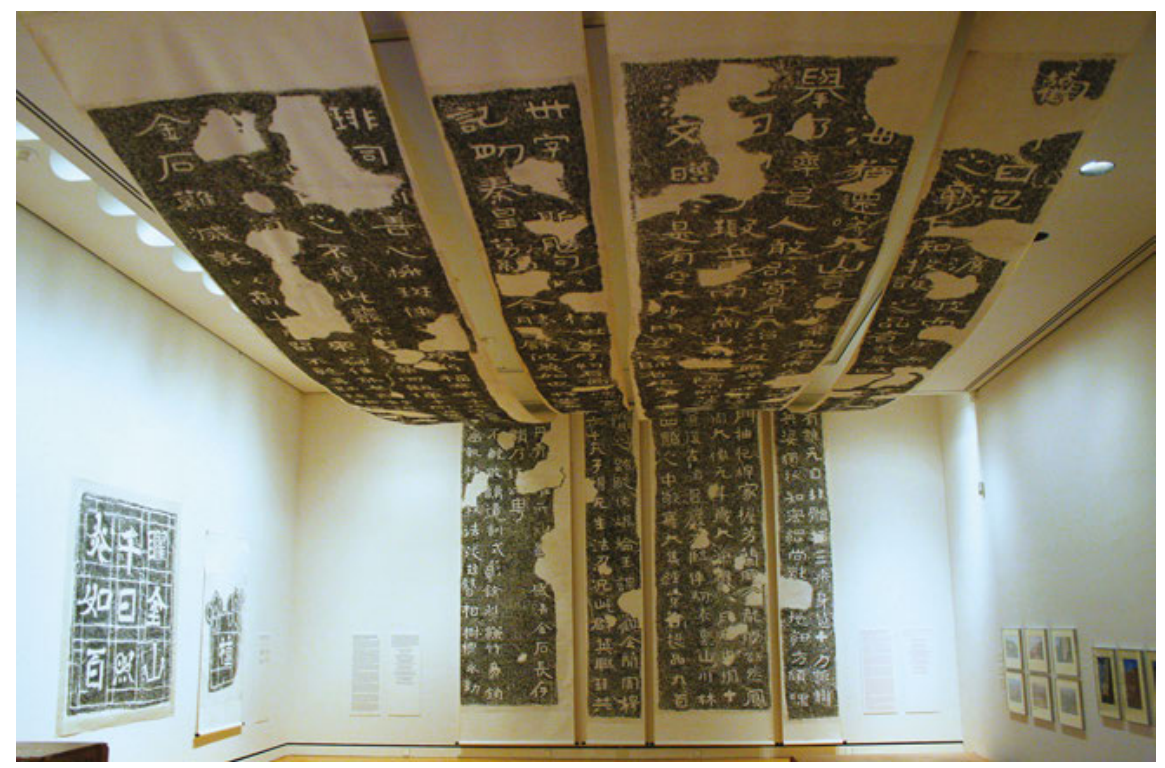

Figure 5.4: Rubbing of the Stone Hymn exhibited at the Museum für Ostasiatische Kunst, Cologne, 2009.

Epigraphers first recorded the Stone Hymn at the end of the $18^{\text {th }}$ century. Huang Yi 黄易 (1744-1802), who has been called an early Chinese field archaeologist, went to Mount Tie and painted a sketch, which, in 1797, he included in an album with 24 small pictures entitled Illustrations of my Visits to Stelae at the Foot of Mount Dai (Dailu fangbei $t u$ 岱麓訪碑圖). ${ }^{7}$ In his rendering of Mount Tie, the engraved inscription is not visible, yet in the colophon to his painting Huang Yi writes that the cliff is steep and slippery and that it is difficult to make rubbings. Nevertheless, he obtained a complete set, and, as he proudly points out, after a thousand years he was the first to pay attention to this inscription. He quotes the information that a certain Kuang Zhe 匡喆, a descendant of the Chief Minister of the Han dynasty, Kuang Heng 匡衡 (fl. 48-32 BCE), had the sutra engraved in the "first year of the daxiang era of the August Zhou dynasty," which corresponds to 579 .

In the summer of 1796, Huang Yi had already sent a set of rubbings to the eminent scholar, Ruan Yuan 阮元 (1764-1849). When Ruan Yuan served in Shandong as Director of Studies (xuezheng 學政) from 1793 to 1795, he convened, in his

7 In the National Palace Museum in Beijing. Illustrated in Gugong bowuyuan (2010, 185-193). The leaf with Mount Tie is on p. 190. 
residence in Jinan 濟南, a research cluster of more than a hundred learned members, who studied ancient inscriptions engraved on stone and on bronze objects in the province. He published them in his comprehensive Epigraphic Records of Shandong (Shanzuo jinshi zhi 山左金石志), to which he wrote a preface in 1797. ${ }^{8}$

When compiling his entry on the Stone Hymn in this work, Ruan Yuan made use of the rubbings that he had received from Huang Yi. He bravely attempted a first transcription of the entire text and here showed himself to be highly methodical. He inserted blank squares, where characters had weathered on the rock and did not appear in his rubbings. If he could identify only parts of a character, he printed those parts, and if characters had been written in variant forms, he also printed those. This must have been quite an exacting task for the artisans who cut the wooden printing blocks for Ruan's book.

In his commentary, Ruan Yuan is more specific than Huang Yi, noting that the twelve columns of the text have 52 or 53 characters each, that the diameter of each character is seven inches, and that each of the two large title characters, Stone and Hymn, has a diameter of more than two feet. He further quotes evidence from a local gazetteer that the Kuang family had formerly moved to a village thirty (Chinese) miles north of Zou City, and he assumes that the family was still living there when they had the sutra carved.

Ruan Yuan's entry is typical of the sober, but selective interest of the early epigraphers. They always name place and date of an inscription and, as a rule, they give measurements, the number of columns and characters, and they also identify the calligraphic type of script (Huang Yi calls it symmetrical clerical script, bafen 八分, Ruan Yuan says standard script, zhengshu 正書). They pay much attention to the donors and makers of the inscriptions, their official positions and their family relationships. They are not, however, concerned with the content of the inscription and they show no interest at all in Buddhist issues.

In the following two centuries, more than a dozen epigraphers wrote about the Stone Hymn. By and large they follow Ruan Yuan's scheme, and the data they provide become ever more exact. In 1834, Dong Chun 董純 and Ma Xingyi 馬星翼 are the first to quote the precise date of the inscription, including the day. ${ }^{9}$ In the autumn of 1839, Li Zuoxian 李佐賢 (1807-1876), a native of Shandong and Presented Scholar (jinshi 進士) of 1835, visited Mount Tie. Quoting the Stone Hymn, he identifies the calligrapher, who wrote the adjacent sutra as "the Great Renunciant (śramana), Dharma Master Sengan 大沙門僧安法師.”10 In 1907,

8 Bi and Ruan (1977-2006, 14484b-14485b).

9 Dong and Ma (1995, 469).

$10 \mathrm{Li}$ and Chen (1911, 14195a). There is no character seng 僧 in the Stone Hymn, yet Dharma Master An is today generally identified as Seng’an Daoyi 僧安道一 (fl. 562-579). 
Yang Shoujing 楊守敬 (1839-1915) reproduces the characters of the Stone Hymn with the traditional method of drawing the strokes in double outlines (shuanggou 雙鈎), and he gives a full transcription. ${ }^{11}$ In 1911, the local official Sun Baotian 孫葆田 (1840-1911) attempts another transcription of the text and gives more numbers of characters and exact measurements. ${ }^{12}$

Again, it is astonishing, that the Buddhist nature of the text attracts hardly any attention from these later authors. Nor do they show interest for the large adjacent sutra. The Stone Hymn tells us that the sutra text is the “Piercing the Bodhi Chapter of the Great Collection Sutra 大集經穿菩提品,” but in the $18^{\text {th }}$ century nobody takes any notice. Li Zuoxian and his colleague, Wu Shifen 吳式芬 (1796-1856), who was, like Li, a native of Shandong and Presented Scholar of 1835, are the first to mention the three giant title characters, Dajijing 大集經 (Great Collection Sutra). ${ }^{13}$ Beginning with Ruan Yuan, authors had quoted passages of a few characters, out of context, from the sutra, but they did not discuss its content, religious significance, authorship or date, and they never explored the reasons why the sutra was engraved at this particular place and time, or in these particular historic and social circumstances.

In the twentieth century, epigraphers continued for a while in the traditional mode. They mostly quoted earlier authors without making substantial additions. This only changed in the 1980s, when the Shandong Stone Carving Art Museum (Shandong shike yishu bowuguan 山東省石刻㙯術博物館) in Jinan 濟南 began systematically to survey and document the Buddhist stone inscriptions in Shandong. Specialists from other institutions joined the efforts. More site investigations of the Stone Hymn were made, more characters were identified, more rubbings were taken, and scholars further improved on the reading of the text. About a dozen transcriptions were proposed in the last quarter century. ${ }^{14}$

Nevertheless, even contemporary Chinese scholars are still under the spell of the mighty epigraphic tradition that Ruan Yuan initiated: they concentrate on the physical features of the engraved characters; they decipher and measure them and describe their state of preservation; they analyze the calligraphy stylistically, compare it with other inscriptions in the province and try to assign it to a particular calligrapher; they list the names of donors and concentrate on

11 Xie Chengren (1988, vol. 10, transcription 419-419; double outlines 420-698).

12 Sun Baotian (1977-2006, 9253b-9254a).

13 Li and Chen (1911, 14195a), Wu Shifen (1937, vol. 28:21153a).

14 Listed in Buddhist Stone Sutras in China, Shandong Province, vol. 2 (see note 5 above), 172-174. The most thoroughly annotated transcription is Zhang Guangcun (2003). Partial transcription and English translation in Harrist (2008, translations: 166, 180; transcription: 294). 
their titles and official positions. Here, Zhang Zong's 張總 research has brought clarification about the roles that different individuals played in the sutra carving project: the Kuang family were the fund raisers, local officials were the donors, and three individuals, who are named in other colophons, were the chief overseers of the project. ${ }^{15}$ Suggestions have also been made as to who the anonymous author and the anonymous calligrapher of the Stone Hymn might have been, yet a convincing conclusion has not been reached. ${ }^{16}$

When our team established the reading of the Stone Hymn that is presented below, we built on the new findings and enriched them with our own investigations on the rock. These included taking photographs at night with strong slanting strobe lighting (Figure 5.5). We further amended worn and unreadable characters by making informed suggestions about the wording that the author would have chosen. Here, Professor Luo Zhao 羅炤, from the Chinese Academy of Social Sciences in Beijing, contributed his knowledge of Buddhist texts. We also examined the Stone Hymn in its larger geographical, social and religious context and viewed its calligraphic style in a wider perspective. ${ }^{17}$ These routes of analysis in our main publication are not repeated here, but the content and the structure of the text will be discussed in the following. ${ }^{18}$

The Stone Hymn is the most extraordinary of all colophons accompanying engraved Buddhist sutras and sutra passages in Shandong. It is a beautiful piece of writing, a superb example of the literature of the time. The anonymous author chose an elegant and rare vocabulary and arrests the reader with evocative imagery and vivid metaphors.

The Stone Hymn consists of a main text in verse, interspersed with prose, which in spite of its length epigraphers have called the Preface ( $x u$ 序). It has five parts in ten columns. The short hymn proper (song 頌) follows in two columns. The first part of the Preface sets the scene; it consists of verses of four, five, and six character lines. Indeed, almost the entire text is written in verse, with only few exceptions: the second part on the donors and the central third part on the dedication each begin with a few words in prose; another short prose section is

15 See Zhang Zong's discussion of Mount Tie in Buddhist Stone Sutras in China, Shandong Province, vol. 2 (note 5 above), 100-105.

16 Wang and Lai $(1989,42)$ suggest that the calligraphy was written by a disciple of An Daoyi, and so thinks Hu Xinli (1989, 45). Zhang Guangcun (2006, 227) argues that the donor Sun Qia 孫洽, who is named in another engraved colophon, wrote both, the text and the calligraphy.

17 See Ledderose (2013).

18 Modern authors have not yet analyzed the content of the Stone Hymn. In Wang and A $(1990,2)$ Wang Jun 王鈞 merely lists, but not in sequence, seven topics that he sees treated in this text. 


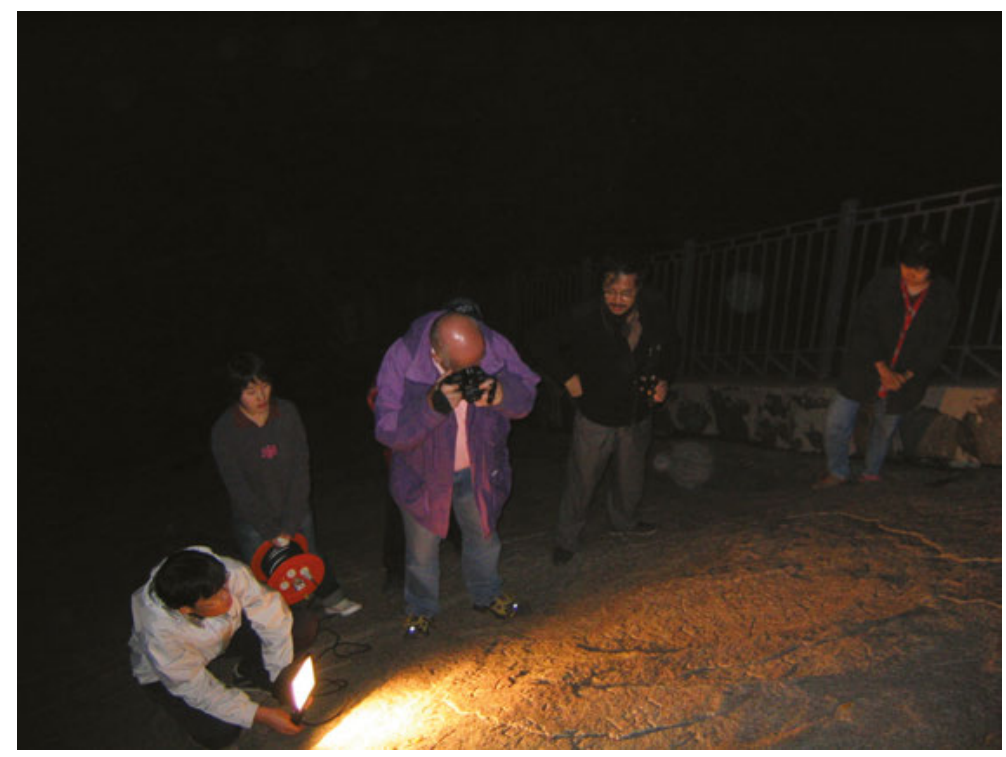

Figure 5.5: Taking photographs of the engraved text at night.

found in the second part, two more in the third part, and one in the fourth part. Yet otherwise, the fourth part on the sutra engraving and the fifth part on the end of the eon are entirely written in verse, with lines of four or six characters. The hymn proper, after a short introduction, also consists of poetic language throughout: six stanzas with four verses each and a last stanza with two verses; each verse has four characters.

The first part, as is usual in votive texts, opens up a wide perspective on the Buddhist teaching and the value of sutras. It evokes the ephemeral nature of the world, including our fragile human existence. Rescue can only come through the knowledge of the correct texts that save and protect.

The second part introduces the donors of the sutra engraved next to the Stone Hymn, and to which the Stone Hymn is the colophon. Kuang Zhe and his four younger brothers are listed by name, and here the reader learns that they are descendants of the Han Chief Minister, Kuang Heng. These virtuous and insightful disciples of the Buddha are aware of the precarious state of the cosmos. They "know that the vast hawsers of heaven have long been deficient and discern that the earth's pivot is near collapse. They sigh that yet the great blue sea also changes and bemoan that even Mount Tai falls." A second group of donors are called the "willows and catalpas of their lineages, fragrant orchids of their 
families." Finally, there is a Buddhist lay society; it may have contributed most of the funds.

The words of part three, the central part of the text, preserve the essence of the dedication ritual, which must have been performed when the engraving of the sutra was completed. First, the sutra is anchored in space and time. It was dedicated: "on the seventeenth day, a bingzi day, of the eighth month, which began on a gengshen day, Jupiter in Pisces, first year of the daxiang era of the August Zhou dynasty.” This elaborate date corresponds to September $23^{\text {rd }}, 579$.

Then the sutra on Mount Tie - and, implicitly, the Stone Hymn - are placed in a cultural geography. The author begins by naming Xiaqiu 瑕丘 in the vicinity, which was the administrative center of Yanzhou 交州 Prefecture. It is known that there were, at the time, an important monastery and a nunnery at Xiaqiu. The monks, who did the engraving, may have had connections with these institutions.

Like many writers of solemn texts, the present author, too, moors his subject at a node where two axes cross, a major north-south axis, and a secondary east-west axis. In this case, the secondary axis reaches, in the east, to Mount Jian 尖山 (here called Cliff of Zhang 昌箃) and, in the west, to the post road, while the main axis points to Mount Yi 嶧山 (here called Mount Zhu Yi 制嶧) in the south, which rises "majestically... its peak reaching the Milky Way," and in the north to the "looming magnificence of Mount Tai 泰山, ... the sacred mountain parting the clouds."

The mountains in the south and east, and probably the post road stations in the west, could be seen by someone reading the sutra and the Stone Hymn while standing on Mount Tie's southern slope. Mount Tai in the north, however, is beyond sight. Only if the beholder climbs up to the 118 meter high ridge above the sutra and, even further, to the peak of Mount Gang behind it, at 235 meters, then no other range will obstruct his view toward Mount Tai. On an unusually clear day, he might be able to make out this most sacred of all holy mountains in China in the far distance, 94 kilometers away. At 1,545 meters, its peak is the highest elevation in Shandong.

The deeper reason, why the writer draws the reader's attention to the two mountains, Yi and Tai, is their prominence in political and cultural history. The First August Emperor of Qin (Qin Shi Huangdi 秦始皇帝; r. 221-210 BCE) had stelae erected here to commemorate and celebrate his unification of the realm. In the second half of the $6^{\text {th }}$ century, Buddhists in northern China now rejoiced in celebrating a new unification of their land, this time under the Buddha. When the Stone Hymn was completed in 579, the short but atrocious Buddhist persecution, which had raged in Shandong in 577/578, had come to an end. In 
earlier years, two sutra passages had already been placed on Mount Yi in 564 and in 570-572, as well as on Mount Jian in 575. Mount Ge 葛山, still further to the east, would be engraved in the following year, 580, and in these same years (the precise date has been lost) Mount Tai was honored with a spectacular inscription of the Diamond Sutra (Jingangjing 金剛經). Together, the inscriptions on these mountains transformed the region into a land of the Buddha. By invoking Mount Yi and Mount Tai, the author of the Stone Hymn affirms that these two venerable peaks - including their ancient imperial aura - had now been fully integrated into the Buddhist realm.

The officiant of the dedication ritual was the Great Renunciant, Dharma Master An, a monk of deepest insight and a calligrapher of the highest order. He wrote out the "Piercing the Bodhi Chapter" of the Great Collection Sutra. The last sentence in the dedication names the fundamental reason for the entire enterprise: "to leave behind these surpassing words in order [...] to rescue the world." Here the author of the Stone Hymn takes up the topic that he had already raised in the first and second parts, namely that the engraved chapters from the Buddhist scriptures will "save and protect" in a time, when the "earth's pivot is near collapse."

In his fourth part, the author narrates how the engraved sutra was produced. He describes the format, which had the shape of an overwhelming stele: "Six dragons encircle it above, their mouths glowing with five-colored [...] clouds; two tortoises crouch below, their shells supporting the path of three steps." Compared with these achievements, similar ancient, pre-Buddhist feats in China, appear trivial, and that even includes the occasion, when the Buddha himself delivered the sermon as "twelve nayuta of beings put forth the bodhi mind (i.e. set their minds on Unsurpassed Correct Perfect Enlightenment), and sixteen thousand gods attained the Acceptance that dharmas are Without Birth.” The reason for this boastful claim is simple: the sutra preached by the Buddha was only heard once; engraved into the rock, however, it will last forever.

The fifth part consists of three and a half stanzas in which the author explains how the stone sutra will endure. Harking back to his first part, where he bemoaned the dire state of the world, he now directs the reader's view to the end of our eon. He refers to the anxieties of Buddhist believers of the period, who were fearfully expecting the end of the Dharma (mofa 末 法). Yet, the author assures us, the sutra hewn into the solid rock will not be affected by the deluge and the scorching winds of the final inferno. In the next world age, it will still be available and make the teachings of the Buddha known again.

Finally, the hymn proper repeats in succinct, poetic language salient elements from the main text. The one major addition concerns the calligraphy, 


\section{Translation*}

石頌 Stone Hymn.

\section{I 引言：佛法ＩIntroduction: The Buddhist Teaching}

\begin{tabular}{|c|c|}
\hline /1/觀行曰 & As the Contemplation of Practice says: \\
\hline 沧海永澹 & The great blue sea rolls forever, \\
\hline 清波而難守 & and the clear waves are hard to hold. \\
\hline 赤電興震 & The red lightening rises and quakes, \\
\hline 朱光而易滅 & and the vermillion radiance quickly perishes. \\
\hline 但以 & And yet, \\
\hline 四毒纏躬 & the Four Poisons entangle the body, \\
\hline 八疵縈骨 & the Eight Faults wind around the bones. \\
\hline 穢納皆羅 & The net of the defilements ensnares us all. \\
\hline 孰有誰无 & Who is free of them, who is not? \\
\hline 自非 & Those, whose \\
\hline 體括三乗 & frame does not encompass the Three Vehicles \\
\hline 身苞十力 & and whose body does not enclose the Ten Powers, \\
\hline $\begin{array}{l}\text { 詎辯/2/口口之章 } \\
\text { 鳥知救護之品者哉 }\end{array}$ & $\begin{array}{l}\text { cannot understand the texts that }[\ldots][\ldots] \text {, } \\
\text { and have no way to know the chapters that save and protect! }\end{array}$ \\
\hline
\end{tabular}

II 供飬人 II The Donors

是叭有信佛弟子匡 喆及弟顯口祖珎漢 丞相衡之苗裔也

Thus, there were the devout disciples of the Buddha, Kuang Zhe and his younger brothers, Xian, [.. .], Zu, and Zhen, descendants of the Han Chief

秀徳自天 Minister [Kuang] Heng,

英姿獨拔 endowed with the excellent virtue bestowed by Heaven,

知宏網尚缺

察地紐方傾 outstanding in their heroic bearing.

嘆 $/ 3 /$ 沧海猶遷 Knowing that the vast hawsers of heaven have long been deficient and discerning that the earth's pivot is near collapse,

嗟太山言落

遂 they sighed that yet the great blue sea also changes,

棄烏塗而在懷 and bemoaned that even Mount Tai falls.

Consequently,

收清骹而口府 and they have [...] within their bowels the acceptance of the pure body they have embraced within their hearts the renunciation of the bemired paths [of Buddhism].

拎是乃 Thereupon,

與同義人李桃湯口 along with the likeminded persons, Li Tao, Tang [. . .], [Tang] Tou, and 娥等 others

可謂- - they can be called

門抽杞梓等 willows and catalpas of their lineages,

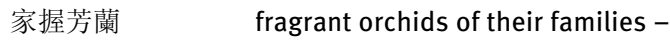

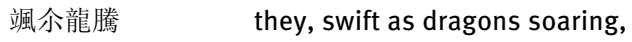

豁然鳳/4/擧等 sudden as phoenixes taking flight,

乃率邑人 led the people of this lay society, 


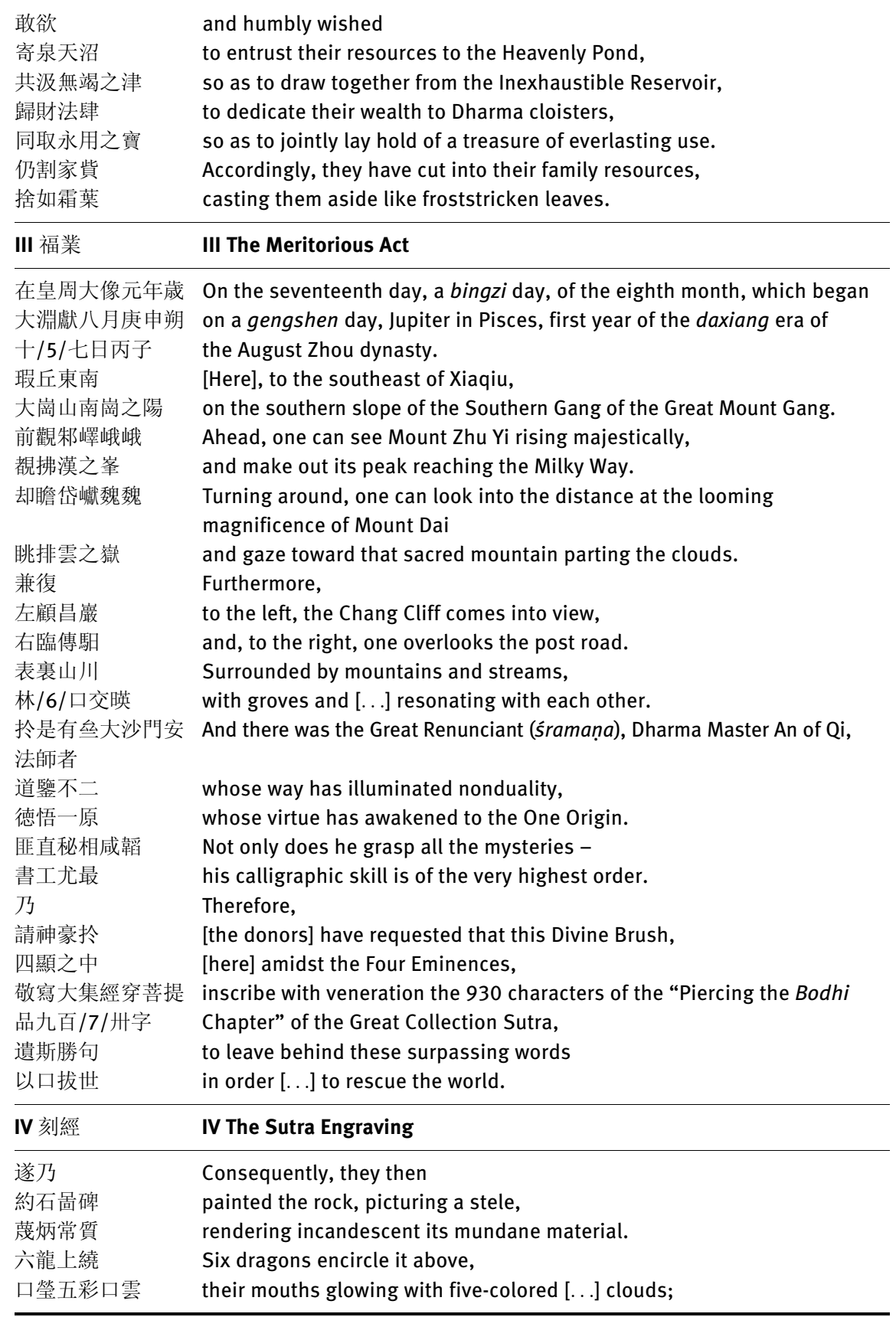




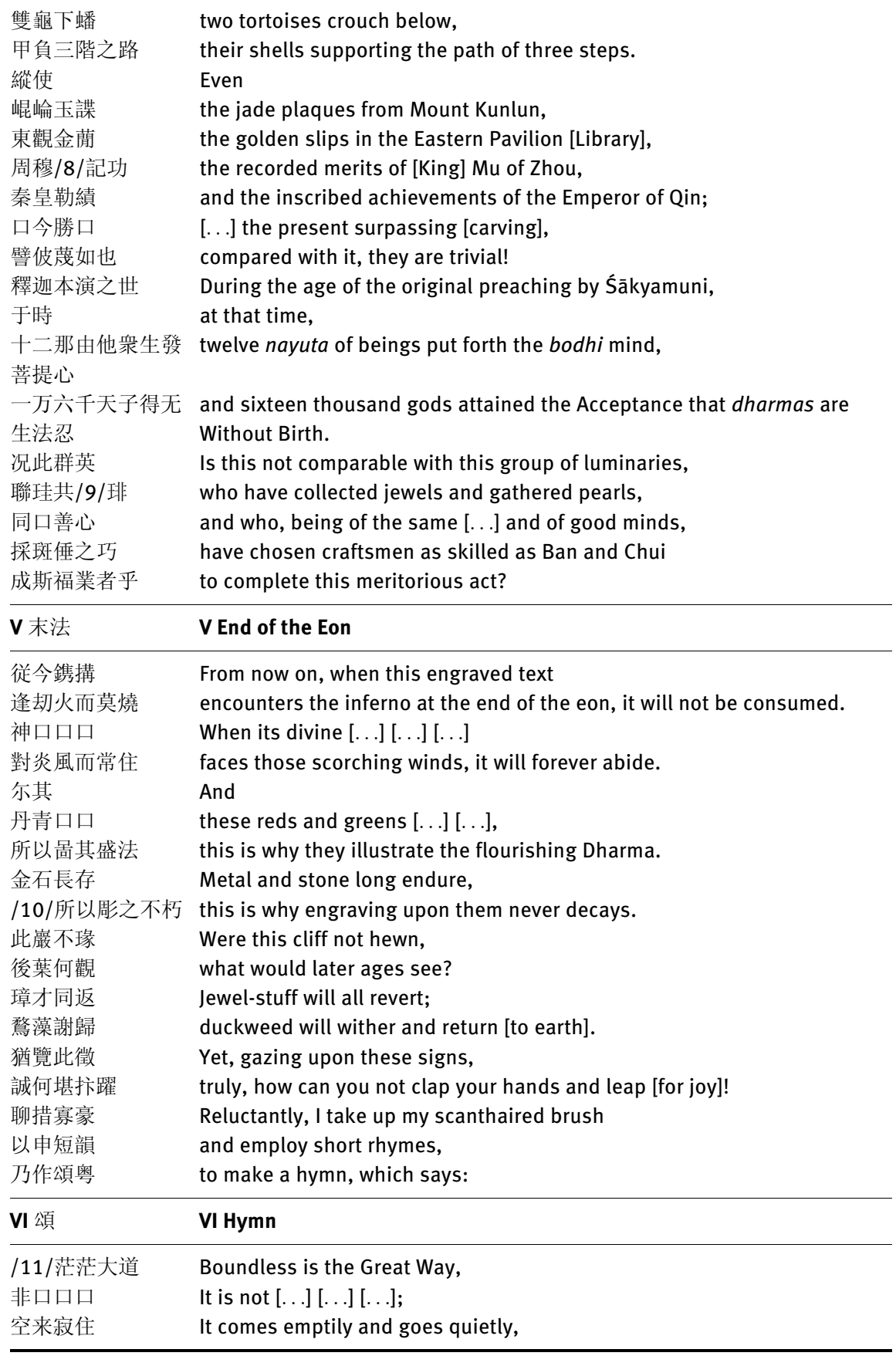


能卷能舒

想口口岸

口離陷途

稱肌代鳥

放鴿殘躸

六度常滿

三空不缺

敢緝遺訓

式彰餘烈

縑竹易銷

$/ 12 /$ 金石難滅

託以高山

永留不絕

尋師珤翰

區口口高

精跨羲誕

妙越英乿

如龍蟠雾

似鳳騰霄

聖人幽軌

神口秘法

従茲䫢相

樹標永却

It can roll up and it can unfold.

Thinking [...] [...] the shore,

[...] he avoids falling into the [dark] paths;

Weighing his flesh to replace the bird,

He frees the pigeon by mutilating his body.

The Six Perfections are ever complete,

The Three Emptinesses are not lacking;

They ventured to gather the instructions handed down

To glorify the achievements bequeathed.

Silk and bamboo are easily ruined,

But metal and stone are hard to destroy;

Entrusting [the texts] to a high mountain,

They will last forever without end.

Seeking the master's treasured brushwork,

In all regions [...] [...] high;

Its refinement surpasses [Wang] Xi[zhi] and [Wei] Dan,

Its marvels exceed [Zhang Bo]ying and [Zhong] You;

As dragons coiling in the mist,

Like phoenixes soaring in the sky.

The recondite tracks of the Sage,

And the secret practices of the Divine [...],

With these magnificent marks,

Their banner is raised for the endless eons.

* The translation was done by the research group of the Heidelberger Akademie der Wissenschaften, including Chen Liang 陳亮, Paul Copp 柏剛, Funayama Toru 船山徹, Eric Greene 葛利尹, Ho Wai Ming 何偉明, Lothar Ledderose 雷德侯, Luo Zhao 羅炤, Ryan Richard Overbey 歐銳恩, Jessica Rawson 羅森, Tsai Suey-Ling 蔡穗玲, Claudia Wenzel 溫狄㛒. Footnotes, in which we explain the reasons for our reading of the characters will be found in Buddhist Stone Sutras in China, Shandong Province vol. 2 (note 5 above), 160-162.

whose excellence, the author assures us, surpasses even that of Wang Xizhi 王羲之 (303-361). This is a bold claim, indeed, because Wang Xizhi was universally hailed as the greatest master of all ages.

As the reader looks back over the text, two topics stand out. The author emphasizes several times that engraving the sutra into the enduring rock will guarantee the survival of the Buddhist teaching into the next world age and so rescue mankind. The second topic, which comes up more than once, is the praise for the aesthetic value of Dharma Master An's calligraphy. The calligraphic tradition is at the core of Chinese culture, and its roots reach far back into a pre-Buddhist period. The fact that a Buddhist monk, and possibly one with a foreign background, was recognized for his supreme achievement in this quintessentially Chinese art, was incontrovertible proof that, by the end of the 
sixth century, the foreign religion had fully taken root in its new homeland and had appropriated some of its central cultural values. It was a successful exercise in transculturality.

\section{References}

Aikawa Masayuki 相川政行. 2003. “Tieshan Daji jing he jingsong shufa yanjiu 鐵山大集經和經 頌書法研究 [Research on the Calligraphy of the 'Great Collection Sutra' and the 'Sutra Hymn’ of Mount Tie].” In Beichao moya kejing yanjiu (xu) 北朝摩崖刻經研究 (續) [Research on the Sutras Engraved on Polished Cliffs during the Northern Dynasties, vol. 2], edited by Shandong shike yishu bowuguan 山東石刻㙯術博物館, 135-157. Hong Kong: Tianma tushu youxian gongsi 天馬圖書有限公司.

Aikawa Masayuki 相川政行. 2004. “Shujōshi Tetsusan「Daishūkyō」daikaku to「Sekishō」 no kenkyū 邹城市鐵山「大集経」題刻と「石頌」の研究 [Research on the main engraving of the Great Collection Sutra and the Stone Hymn on Mount Tie at Zoucheng]." Heisei 16 nen Risshō daigaku bungakubu kenkyū kiyō 平成 16 年立正大学文学部研究紀要 (The Academic Journal of the Faculty of Letters, Rissho University) 20:1-17.

Bi Yuan 畢沅, and Ruan Yuan 阮元, eds. 1977-2006. Shanzuo jinshi zhi 山左金石志

[Epigraphic Records of Shandong]. In Shike shiliao xinbian 石刻史料新編, series 1, vol. 19:14325-14802.

Dong Chun 董純, and Ma Xingyi 馬星冀. 1995. “Zou Xian zhi gao 鄒縣志稿 [Draft of the Gazetteer of Zou County]” (preface 1834). In Lidai Zou Xian zhi shizhong 歷代鄒縣志十種 [Ten Historical Gazetteers of Zou County], edited by Liu Fengtong 劉鳳桐 and Zhang Xinmin 張信民, 403-510. Beijing: Zhongguo gongren chubanshe 中國工人出版社.

Gugong bowuyuan 故宮博物院, ed. 2010. Penglai suyue: Gugong cang Huang Yi Han Wei beike teji 蓬莱宿约: 故宮藏黄易漢魏碑刻特集 [Revisiting Penglai: Stelae Engravings from the Han and Wei Dynasties from Huang Yi's Special Collection Preserved at the Palace Museum]. Beijing: Zijincheng chubanshe 紫禁城出版社.

Harrist, Robert E. 2008. The Landscape of Words: Stone Inscriptions from Early and Medieval China. Seattle: University of Washington Press.

Hu Xinli 胡新立. 1989. “Zou Xian Sishan Beichao moya kejing 鄒縣·四山’北朝摩崖刻經 [The Sutras Engraved during the Northern Dynasties on Polished Cliffs of the 'Four Mountains' in Zou County]." Shufa 書法 65, no. 2:44-47.

Lai Fei 賴非. 2007. Shandong Beichao fojiao moya kejing diaocha yu yanjiu 山東北朝佛教摩崖 刻經調查與研究 [Field Work and Research on the Buddhist Sutras Engraved on Polished Cliffs in Shandong during the Northern Dynasties]. Beijing: Kexue chubanshe 科學出版社. Ledderose, Lothar. 2013. "Scaling the Cliffs." Orientations 44, no. 1:51-58.

Ledderose, Lothar, series editor, $2014 \mathrm{ff}$. Buddhist Stone Sutras in China, Zhongguo fojiao shijing 中國佛教石經. Wiesbaden: Harrassowitz; Hangzhou: China Academy of Art Press.

Ledderose, Lothar. 2016. “The Largest Colophon in China: The Stone Hymn 石颂 of 579 AD at Mount Tie 鐵山. Chūgoku saidai no okugaki. 579 nen ni Tetsuzan ni kizamareta Sekishō 中国最大の奥書. 579 年に鐵山に刻まれた《石颂》.”In Higashi Ajia ni okeru Sho no bigaku no dentō to henyō 東アジアにおける《書の美学》の伝統と変容 [Tradition and Transformation in Aesthetics of East Asian Calligraphy], edited by Kambayashi 
Tsunemichi 神林恒道, Kaya Noriko 萱のり子, Tsunoda Katsuhisa 角田勝久, 81-97. Tōkyō: Sangensha 三元社.

Li Zuoxian 李佐賢, and Chen Zhu 陳洙, postface 1911. Shiquan shuwu jinshi tiba 石泉書屋金石 題跋 [Colophons to Epigraphica from the Stone Well Studio]. In Shike shiliao xinbian, series 2, vol. 19:14189-14196.

Museum für Ostasiatische Kunst Köln and Heidelberger Akademie der Wissenschaften, eds. 2009. The Centenary of the Museum of East Asian Art Cologne. The Heart of Enlightenment: Buddhist Art in China 550-600. Köln: Museum für Ostasiatische Kunst Köln.

Shike shiliao xinbian 石刻史料新編 [New Edition of Historical Materials Carved on Stone]. 1977-2006. Edited by Xinwenfeng chubangongsi bianjibu 新文豐出版公司編輯部, 4 series, 100 vols. Taibei: Xinwenfeng chubanshe 新文豐出版社.

Sun Baotian 孫葆田. 1977-2006. Shandong jinshi zhi 山東金石志 [Epigraphic Records of Shandong]. In Shike shiliao xinbian石刻史料新編, series 2, vol. 12:9147-9392.

Wang Jun 王鈞, and A Tao 阿濤, eds. 1990. Sishan moya kejing 四山摩崖刻經 [Sutras Engraved on Polished Cliffs of the Four Mountains]. Beijing: Zhishi chubanshe 知識出版社.

Wang Sili 王思禮, and Lai Fei 賴非. 1989. “Tieshan Shisong de chubu kaocha yu yanjiu 鐵山石 頌的初步考察與研究 [A Preliminary Investigation and Research of the Stone Hymn on Mount Tie]." Shufa 書法 65, no. 2:41-43.

Wu Shifen 吳式芬. Undated; ed. 1937. Jinshi huimu fenbian 金石彙目分編 [Categorized Edition of an Assembled Catalog of Epigraphica]. In Shike shiliao xinbian, series 1, vol. 27-28: 20651-21591.

Xie Chengren 謝承仁, ed. 1988. Yang Shoujing ji 楊守敬集 [Collected Works of Yang Shoujing]. 10 vols. Wuhan: Hubei renmin chubanshe 湖北人民出版社.

Zhang Guangcun 張廣存. 2003. “Tieshan ke Jingsong shidu bing jiaozhu 《鐵山刻經頌》識讀 並校注 [Reading and Critical Annotation of the "Hymn to the Sutra Engraved at Tieshan'].” In Beichao moya kejing yanjiu ( $x u$ ) 北朝摩崖刻經研究 (續) [Research on the Sutras of the Northern Dynasties Engraved on Polished Cliffs, vol. 2], edited by Shandong shike yishu bowuguan 山東石刻藝術博物館, 215-235. Hong Kong: Tianma tushu youxian gongsi 天馬圖書有限公司.

Zhang Guangcun 張廣存. 2006. “Tieshan Beichao kejing xinkao si ti 鐵山北朝刻經新考四題 [Four Questions on the Latest Research on Sutras Engraved on Polished Cliffs at Mount Tie during the Northern Dynasties].” In Beichao moya kejing yanjiu (san) 北朝摩崖刻經研 究 (三) [Research on the Sutras of the Northern Dynasties Engraved on Polished Cliffs, vol. 3], edited by Shandong shike yishu bowuguan 山東石刻藝術博物館 and Hebei Sheng Handan Shi wenwuju 河北省邯鄲市文物局, 221-231. Hohhot: Neimenggu renmin chubanshe 內蒙古人民出版社. 
